\title{
Evaluation of the Marginal Gingival Health Using Laser Doppler Flowmetry
}

\author{
Hakan DEVELIOGLU ${ }^{1}$ \\ Bülent KESIM ${ }^{2}$ \\ Aykut TUNCEL ${ }^{3}$
}

\author{
${ }^{1}$ University of Cumhuriyet, Faculty of Dentistry, Department of Periodontology, Sivas, Turkey \\ ${ }^{2}$ University of Erciyes, Faculty of Dentistry, Department of Prosthodontics, Kayseri, Turkey \\ ${ }^{3}$ University of Cumhuriyet, Faculty of Dentistry, Department of Prosthodontics, Sivas, Turkey
}

\begin{abstract}
The purposes of this study were to compare the gingival blood flow (GBF) in test sites (teeth retaining fixed partial dentures) and control sites (contralateral natural teeth) and investigate whether there is any relationship between clinical indices and GBF values. Twelve healthy subjects ( 6 females and 6 males) aged 20 to 54 years were enrolled this study. The GBF was measured from the middle point of the marginal gingiva in the test and control sites using laser Doppler flowmetry (LDF). Additionally, plaque index, gingival index and probing depth measurements were recorded. Statistically significant difference $(\mathrm{p}<0.05)$ was found between the test and control sites for marginal GBF. In contrast, no significant difference ( $>>0.05$ ) was found between test and control sites with respect to the clinical indices, except for plaque index. The findings of this study suggest that there is a significant relation between resin-bonded fixed partial dentures with margins located subgingivally and marginal GBF. Clinical indices are helpful to collect information about the clinical health status of gingival tissues, but GBF is a good tool to measure gingival tissue blood flow and assess periodontal health. In conclusion, laser Doppler flowmetry can be used together with clinical indices to evaluate the marginal gingival health.
\end{abstract}

Key Words: Resin-bonded fixed partial dentures, marginal gingival blood flow, laser Doppler flowmetry.

\section{INTRODUCTION}

A healthy coexistence between resin-bonded fixed partial dentures and their surrounding periodontal structures is the goal of the conscientious dentist and the expectation of the informed patient (1). Dental restorations and periodontal health are inseparably interrelated. Marginal adaptation, contouring, proximal contacts and surface smoothness have a critical biologic impact on gingival and supporting periodontal tissues (2). Restorations can alter tooth form, surface continuity and the relationship of the restored tooth with the periodontal tissues, adjacent teeth and contralateral teeth (3).

The most important factor controlling the effects of restorations on gingival health is the localization of the crown margin relative to the gingival margin (4). Lang et al. have demonstrated that the inflammatory response of the marginal gingiva close to restorations with imper- fect subgingival margins is primarily not due to the great plaque accumulation, but to a more specific alteration of the composition of the subgingival microflora (5).

A subepithelial vascular plexus consisting of a capillary plexus with loops arching towards the epithelium characterizes healthy gingiva. Gingival inflammation results in increased vascularity with more capillary loops, larger vessel size and slower blood flow, and restriction of the afferent blood vessels. Inflammationinduced vasculitis and vascular permeability allow lymphocytes and serum substances to leak into the connective tissue, which can induce an immune response that results in tissue destruction (6)

The purposes of this study were to compare the gingival blood flow (GBF) in test sites (teeth retaining fixed partial dentures) and control sites (contralateral natural teeth) and investigate whether there is any relationship between clinical indices (CI) and GBF. 


\section{MATERIAL AND METHODS}

This study involved 12 healthy subjects (6 females and 6 males) aged 20 to 54 years (mean $35.42 \pm$ 1.86) who have attended to the Department of Prosthodontics of Faculty of Dentistry of Cumhuriyet University. Informed consent was obtained from all patients before the measurements.

As inclusion criteria, the patients should have a resin-bonded fixed partial denture on either the upper or the lower arch and contralateral natural teeth in the same arch. The dentures should have the same number of retainers as their contralateral natural teeth. Patients with any systemic problem, submitted to any antibiotic therapy within the past 6 months or smokers were not enrolled in the study.

Phase-N (Unitech, Le Mesnil Le Roi, France) CrNi alloy and Biodent (Dentsply Caulk, Milford, DE, USA) veneering material were used in fabrication of resin-bonded fixed partial dentures. All fixed dentures had ridge-lap pontics. Veneering materials were polymerized in Ivomat IP3 unit (Ivoclar Vivadent, Bürs, Austria) and the dentures were cemented with Adhesor Carbofine (Spofa Dental, Praha,Czechoslovakia) zinc polycarboxylate cement.

Marginal GBF measurements were taken with a laser Doppler flowmetry (LDF) equipment (Periflux 4001 Master, Perimed AB, Jarfalla, Sweden). Custommade 3-mm-thick acrylic splints (Ortocryl 2000, Dentaurum, Pforzheim, Germany) with two holes were created in such a way that the flowmeter probe could be placed on the midpoint of gingival margin external surface. Measurements were taken from the buccal site of the marginal gingiva adjacent to the fixed denture retainers (test sites; $\mathrm{n}=24$ measurement points) and the marginal gingiva adjacent to the contralateral natural teeth (control sites; $\mathrm{n}=24$ measurement points) as a mean of values recorded for $30 \mathrm{~s}$ and expressed as perfusion unit (PU). Gingival index (7), plaque index (8) and probing depth were also recorded.

Data were analyzed statistically by Mann-Whitney U-test, chi-square test and Fisher's exact test at 5\% significance level.

\section{RESULTS}

Forty-eight dental sites (half test sites and half control sites) from 12 patients were examined the present study. Twenty-one test surfaces (87.49\%) were plaque-covered and gingival bleeding was observed in 5 test sites (20.83\%). Eleven control surfaces (37.5\%) were covered with plaque and gingival bleeding was observed in 1 control site.

Statistically significant difference was found between the GBF values recorded in the test $(71.99 \pm 7.58)$ and control sites $(39.56 \pm 4.44)(\mathrm{p}=0.001 ; \mathrm{p}<0.05)$. Probing depth recorded for the test and control sites were $1.71 \pm 0.13 \mathrm{~mm}$ and $1.25 \pm 0.08 \mathrm{~mm}$, respectively ( $>0.05$ ). Plaque index results were the following: test sites - absence: $12.5 \%$ and presence: $7.5 \%$; control site - absence: $54.2 \%$ and presence: $45.8 \%$. There was a statistically significant difference between both sites $\left(p<0.05 ; x^{2}=9.37\right)$. Gingival inflammation results were the following: test sites - healthy: $79.2 \%$ and diseased: 20.8\%; control site - healthy: $95.8 \%$ and diseased: $4.2 \%$. No correlation between gingival indices of both sites was found $(\mathrm{p}=0.188 ; \mathrm{p}>0.05)$.

\section{DISCUSSION}

The relation between resin-bonded fixed dentures and periodontal health has been investigated since the 1950s. Although the abutment teeth and dental restorative materials have received more attention, the periodontal therapy, errors occurred during tooth preparation, impression and temporary restoration are shown to have negative effects on the periodontal tissues $(7,8)$.

The location of crown margins in the preparation of restorations has been widely discussed. Löe (9) reported that subgingival crown margins caused periodontal problems and Leon (10) emphasized that the subgingival margins were not suitable for periodontal structures. Several investigators $(1,7)$ advocated that subgingival restoration margins caused more gingival inflammation than supragingival margins.

LDF has been extensively used in medical and dental research. Different agents and allergens can alter the gingival blood flow $(11,12)$. Matheny et al. (13) reported that blood flow can be measured non-invasively by LDF method. They measured both the movement of red blood cells and the blood flow in capillary vessels from a small tissue sample ( $1 \mathrm{~mm}^{3}$ on average). Marginal blood flow can also be affected by individual characteristics of the restorations or plaque accumulation index (12).

It has been shown (14) that there is a relationship 
between plaque accumulation, gingival inflammation and tissue microcirculation. Matheny et al. (15) found that gingival microcirculation exhibited a dramatic dynamic change in response to the development and progression of gingivitis. al-Wahadni et al. (16) found higher gingivitis levels on resin-bonded fixed bridges caused by plaque accumulation. Few studies have assessed the marginal blood flow using $\operatorname{LDF}(17,18)$.

Vag and Fazekas (19) investigated the effects of crown margin on gingival health and observed that the LDF technique is a non-invasive method to specter blood flow of tissues. They compared the results of the measurements before restoration, at cementation and after treatment, and found a correlation between gingival index and LDF results. In contrast, in the present study, no statistically significant correlation was observed between gingival index and GBF values in neither test or control sites.

This study compared clinical indices of marginal gingiva and GBF readings between denture retainers and their contralateral natural teeth within the same dental arch. There was a statistically significant difference in marginal GBF measurements between the test and control sites $(\mathrm{p}<0.05)$. The margins of all fixed partial dentures examined in this study were located subgingivally. It is likely that the higher blood flow values of test sites can be attributed to the more severe gingival inflammation caused by greater plaque accumulation on the margins of the resin-bonded dentures. Altered microcirculation is ususally observed in inflamed tissues. Subgingival restoration margins might bring forth an additional inflammatory effect on the gingival tissue (20).

The findings of this study showed that there was no relationship between the GBF values and clinical indices on both test and control sites. Clinical indices give information about the clinical status of the tissues while GBF values provide data about microcirculation. Resin-bonded fixed partial dentures with margins located subgingivally altered gingival blood flow. Blood flow values changed when the microcirculation is altered. Clinical indices are helpful to collect information about the clinical health status of the gingival tissues, but GBF is a good tool to measure tissue blood flow and assess periodontal health.

In conclusion, laser Doppler flowmetry can be used together with clinical indices to evaluate the marginal gingival health.

\section{RESUMO}

Os objetivos deste estudo foram comparar o fluxo sangüíneo gengival (FSG) em sítios teste (dentes retentores de próteses parciais fixas) e sítios controle (dentes naturais contralaterais) e investigar se há alguma relação entre os índices clínicos (IC) e os valores de FSG. Doze indivíduos saudáveis (6 mulheres e 6 homens) com idades entre 20 a 54 anos participaram deste estudo. O FSG foi medido no ponto médio da gengina marginal em ambos os sítios teste e controle utilizando dopplerfluxometria a laser (DFL). Além disso, as medidas referentes ao índice de placa, índice gengival e profundidade de sondagem foram registradas. Foi observada diferença estatisticamente significante $(p<0.05)$ entre os grupos teste e controle para os valores de FSG. Por outro lado, não houve diferença estatisticamente significante ( $>0.05$ ) entre os sítios teste e controle com relação aos índices clínicos, exceto para o índice de placa. Os achados deste estudo sugerem que existe uma relação significante entre próteses parciais fixas retidas por resina com margens localizadas subgengivalmente e o FSG marginal. Embora os índices clínicos sejam úteis para coletar informações sobre as condições clínicas dos tecidos gengivais, o FSG é uma ferramenta importante para medir o fluxo sanguíneo tissular gengival e avaliar a saúde periodontal. Em conclusão, a dopplerfluxometria a laser pode ser usada juntamente com índices clínicos para avaliar a saúde gengival marginal.

\section{ACKNOWLEDGEMENTS}

The authors would like to thank Dr. Janos Vag and Dr. Ziynet Çinar for their valuable help and guidance with the statistical analysis.

\section{REFERENCES}

1. Block PL. Restorative margins and periodontal health: A new look at an old perspective. J Prosthet Dent 1987;57:683689.

2. Sachs RI. Restorative dentistry and the periodontium. Dent Clin North Am 1985;29:261-278.

3. Perry DA, McDowell J, Goodis HE. Gingival microcirculation response to tooth brushing measured by laser Doppler flowmetry. J Periodontol 1997;68:990-995.

4. McGuire M. Periodontal restorative interrelationships. In: Carranza FA, Newman MG (editors). Clin Periodontol. 8th ed. USA: WB Saunders Company; 1996. p 723-742.

5. Lang NP, Kiel RA, Anderholden K. Clinical and microbiological effects of subgingival restorations with overhanging or clinically perfect margins. J Clin Periodontol 1983;10:563578.

6. Matheny JL, Abrams H, Johnson DT, Roth GI. Microcirculatory dynamics in experimental human gingivitis. J Clin Periodontol 1993;20:471-475.

7. Löe H, Sillness J. Periodontal disease in pregnancy. Acta Odontol Scand 1963;21:533-551.

8. Sillness J, Löe H. Periodontal disease in pregnancy. II. Correlation between oral hygiene and periodontal condition. Acta Odontol Scand 1964;22:121-135

9. Löe H, Sillness J. Reactions of marginal periodontal tissues to restorative procedures. Int Dent J 1968;18:759-778. 
10. Leon AR. The periodontium and restorative procedures: A critical review. J Oral Rehabil 1977;4:105-117.

11. Herlofson BB, Brodin P, Aars H. Increased human gingival blood flow induced by sodium lauryl sulphate. J Clin Periodontol 1996;23:1004-1007.

12. Baab DA, Öberg PA, Hollaway G. Gingival blood flow measured with a laser Doppler flowmetry. J Periodontol 1986;21:73-85.

13. Matheny JL, Johnson DT, Roth GI. Aging and microcirculatory changes in human gingiva. J Periodontol 1993;20:471475.

14. Daly CG, Highfeld JE: Effect of localized experimental gingivitis on early supragingival plaque accumulation. J Periodontol 1996;23:160-164.

15. Matheny JL, Abrams H, Johnson DT, Roth GI: Microcirculatory dynamics in experimental human gingivitis. J Clin Periodontol 1993;20:578-583.
16. al-Wahadni A, Linden GJ, Hussey DL: Periodontal response to cantilevered and fixed-fixed resin bonded bridges. Eur J Prosthodont Restor Dent 1999;7:57-60.

17. Kerdvongbundit V, Vongsavan N, Soo-Ampon S, Phankosol $\mathrm{P}$, Hasegawa A. Microcirculation of the healthy human gingiva. Odontology 2002;90:48-51.

18. Kerdvongbundit V, Vongsavan N, Soo-Ampon S, Hasegawa A. Microcirculation and micromorphology of healthy and inflamed gingivae. Odontology 2003;91:19-25.

19. Vag J, Fazekas A. Influence of restorative manipulations on the blood perfusion of human marginal gingiva as measured by laser Doopler flowmetry. J Oral Rehabil 2002;29:52-57.

20. Reeves WG. Restorative margin placement and periodontal health. J Prosthet Dent 1991;66:733-736.

Accepted June 4, 2006 